\title{
Forkhead Box Protein P2
}

National Cancer Institute

\section{Source}

National Cancer Institute. Forkhead Box Protein P2. NCI Thesaurus. Code C75491.

Forkhead box protein P2 (715 aa, $\sim 80 \mathrm{kDa}$ ) is encoded by the human FOXP2 gene. This protein is involved in brain development through transcriptional regulation. 